\title{
Generic and Branded Enoxaparin Bioequivalence: A Clinical and Experimental Study
}

\author{
Hamdi Boubaker MD ${ }^{1,8}$, Mohamed Habib Grissa MD ${ }^{1,8}$, Mouna Sassi MD ${ }^{2,8}$, Taher Chakroun MD ${ }^{3}$, Kaouthar Beltaief MD ${ }^{1,8}$, Mohsen Hassine \\ MD ${ }^{4,8}$, Grigoris T Gerotziafas MD ${ }^{5}$, Rabie Razgallah MD ${ }^{6}$, Wahid Bouida MD ${ }^{1,8}$, Riadh Boukef MD ${ }^{7,8}$, Ismail Elalamy MD ${ }^{5}$ and Semir Nouira MD ${ }^{1,8 *}$ \\ ${ }^{1}$ Emergency Department, Fattouma Bourguiba University Hospital, Monasitr 5000, Tunisia \\ ${ }^{2}$ Biological Laboratory, Maternity and Neonatal Medicine Center, Monastir 5000, Tunisia \\ ${ }^{3}$ Regional Blood Transfusion Center, Farhat Hached University Hospital, Sousse 4004, Tunisia \\ ${ }^{4}$ Hematology Department, Fattouma Bourguiba University Hospital, Monasitr 5000, Tunisia \\ ${ }^{5}$ Biological Hematology Department, Hospital Tenon, Paris, France \\ ${ }^{6}$ Research Department, Medis Laboratory Tunisia \\ ${ }^{7}$ Emergency Department, Sahloul University Hospital, Sousse 4011, Tunisia
}

${ }^{8}$ Research Laboratory (LR12SP18), University of Monastir 5000 Tunisia

\begin{abstract}
Our aim is to compare a new generic version of enoxaparin $\left(\right.$ Enoxa $\left.{ }^{\circledR}\right)$ with the parent brand (Lovenox ${ }^{\circledR}$ ).

We included patients with acute coronary syndrome (ACS) for the clinical study and healthy volunteers for the experimental study. ACS patients were randomly assigned to receive a bolus of Enoxa ${ }^{\circledR}(n=86)$ or Lovenox ${ }^{\circledR}(n=83)$ and serum anti-Xa activity was measured 4 hours thereafter. For experimental study, blood from healthy volunteers was used to compare the effect of both formulations on thrombin generation in citrated platelet-poor plasma (PPP). We measured the half maximal inhibitory concentration of the drug (IC50) that is required to decrease $50 \%$ in-vitro thrombin generation parameters the mean rate index (MRI) and the endogenous thrombin potential (ETP). Both IC50 MRI and IC50 ETP were calculated in PPP.

In ACS patients, serum anti-Xa activity was found not different between $\mathrm{Enoxa}^{\circledR}$ and Lovenox ${ }^{\circledR}$. Median anti Xa activity measured 4 hours after the initial bolus was $0.39 \mathrm{IU}$ anti-Xa/ml $[95 \% \mathrm{Cl} 0.31-0.53]$ and $0.34 \mathrm{IU}$ anti-Xa/ml $[95 \% \mathrm{Cl} 0.27-0.53]$, for the Enoxa ${ }^{\circledR}$ group and Lovenox ${ }^{\circledR}$ group respectively. No difference in major cardiovascular events was observed during hospital stay. In healthy volunteers, IC50 MRI and IC50 ETP were similar between Lovenox ${ }^{\circledast}$ and Enoxa ${ }^{\circledR}[(2.5 \mu \mathrm{g} / \mathrm{ml} \pm 0.2 \mu \mathrm{g} / \mathrm{ml}) \mathrm{versus}(2.3 \mu \mathrm{g} / \mathrm{ml} \pm$ $0.1 \mu \mathrm{g} / \mathrm{ml})]$ and $[(4.8 \mu \mathrm{g} / \mathrm{ml} \pm 0.8 \mu \mathrm{g} / \mathrm{ml})$ versus $(4.1 \mu \mathrm{g} / \mathrm{ml} \pm 0.1 \mu \mathrm{g} / \mathrm{ml})$ respectively for IC50 MRI and IC50 ETP; ( $=0.2)]$. With both formulations, anti-Xa activity and anti-Xa/anti-Ila ratio were similar.
\end{abstract}

The generic enoxaparin Enoxa ${ }^{\circledR}$ met the main regulatory criteria of bioequivalence with the branded product.

Keywords: Equivalence; Enoxaparin; Acute coronary syndrome; Generic

\section{Introduction}

Low molecular weight heparins (LMWHs) are a family of anticoagulants that are widely used in the treatment and the prophylaxis of venous and arterial thromboembolism. In the specific clinical setting of antithrombotic management of acute coronary syndrome (ACS), the LMWH enoxaparin has consistently shown its superiority in terms of efficacy when compared to unfractionated heparin (UFH) and other LMWHs [1-3]. In this clinical indication, enoxaparin is now the gold standard for anticoagulation and is extensively used in everyday practice $[4,5]$. In the last decade, patent rights and supplementary protection certificates of branded enoxaparin have expired raising the opportunity to develop copies of this innovator product. As a consequence, generic enoxaparin appeared on the market in many countries such as China, India and Brazil [6-8]. Similarly, a new generic enoxaparin was recently proposed in Tunisia. From an economic viewpoint, the use of generic enoxaparin results in a considerable savings of healthcare expenditures although some authors have been concerned about the introduction into the market of such copies [9]. Indeed, any generic of enoxaparin should have an equivalent activity and bioavailability as the original molecule. Otherwise, it is difficult to ensure that the benefit/risk ratio of enoxaparin and its copy are equivalent. This study was carried out to assess the bioequivalence of branded enoxaparin (Lovenox ${ }^{\circledR}$; Sanofi US, Bridgewater, New Jersey) with a generic version of enoxaparin (Enoxa'; Medis Laboratory, Tunisia) in patients with ACS and in healthy volunteers using parameters of interest such as plasma anti-Xa and anti-IIa activities and thrombin generation (TG) tests.

\section{Materials and Methods}

This study combined clinical trial conducted in patients with ACS and an experimental study conducted in healthy volunteers.

\section{The clinical study}

This single-dose, randomized-sequence, open-label study was conducted at the emergency department (ED) of Fattouma Bourguiba University Hospital, Tunisia. It was performed in accordance with the revised declaration of Helsinki for Biomedical Research involving human subjects and the Guidelines for Good Clinical Practice. The protocol was approved by the ethics committee of our institution. This trial was carried out between December 2012 and April 2013. Prior to undergoing any screening procedures, all included patients provided written informed consent. Patients were included if they were older than 18 years and fulfilled the criteria of ACS within $48 \mathrm{H}$ of chest pain onset: signs suggestive of ACS without ST-segment elevation myocardial infarction, and electrocardiographic changes

*Corresponding author: Semir Nouira, MD, Emergency Department, Fattouma Bourguiba University Hospital Monastir and Research Laboratory (LR12SP18) University of Monastir 5000 Tunisia, Tel : +216 73532 014; Fax : +216 73460 678; E-mail: semir.nouira@rns.tn

Received June 16, 2015; Accepted July 14, 2015; Published July 21, 2015

Citation: Boubaker H MD, Grissa MH MD, Sassi M MD, Chakroun T MD, Beltaief K MD, et al. (2015) Generic and Branded Enoxaparin Bioequivalence: A Clinical and Experimental Study. J Bioequiv Availab 7: 225-228. doi:10.4172/jbb.1000244

Copyright: (c) 2015 Boubaker H MD, et al. This is an open-access article distributed under the terms of the Creative Commons Attribution License, which permits unrestricted use, distribution, and reproduction in any medium, provided the original author and source are credited. 
compatible with ischemia or elevated levels of cardiac biomarkers. Patients were ineligible if they had any of the following major exclusion criteria: cardiogenic shock, persistent ST-segment elevation, clinically significant hepatic disease, end-stage renal disease requiring dialysis, an increased risk of bleeding, platelet count of less than $50.000 / \mathrm{mm}^{3}$ at the time of screening, a history of pathologic intracranial findings, the use of any heparin within the previous 72 hours, or history of allergy to this drug.

Using a table-generated randomization schedule, eligible patients were assigned to receive an IV bolus of the branded enoxaparin (Lovenox $^{\circledR}$; Sanofi US, Bridgewater, New Jersey) or the generic one $\left(\right.$ Enoxa $^{\circledR}$; Medis Laboratory, Tunisia). We performed this study with at least two lots of Enoxa ${ }^{\circledR}$ and Lovenox ${ }^{\circledR}$. Baseline demographics with clinical history data and results of routine laboratory tests including platelet count, thromboplastin time (PT) and activated partial thromboplatin time (aPTT) were recorded at ED admission. Sample collections were determined in conformity with the current international recommendations for haemostasis tests blood. Sampling was performed at inclusion and 4 hours after the first dose of the LMWH protocol products. Samples were centrifugated for 15 minutes at a speed of $2000-2500 \mathrm{~g}$ and at a temperature around $18^{\circ} \mathrm{C}$. For the assessment of anti-Xa activity, the plasma was aliquoted and stored at $-80^{\circ} \mathrm{C}$. The anti-Xa activity was determined by chromogenic methods using the $\mathrm{STA}^{\circledR}$-Liquid Anti-Xa reagent (Diagnostica Stago, Asnières sur seine, France). Precision studies indicated an intra and an interlaboratory variation $<5 \%$. All the patients were admitted in the cardiology department and managed according to the current practice. A clinical follow-up was conducted for all the included patients until 30 days post-ED admission. All major cardio-vascular events (death, acute reperfusion, stroke) occurring during the follow-up period were recorded.

\section{The healthy volunteers study}

Samples preparation: Venous blood was obtained from 15 healthy volunteers not taking any medication interfering with haemostasis during the last 10 days. Blood was collected with atraumatic antecubital veinipuncture into siliconized vacutainer tubes (Becton Dickinson, Meylan, France) containing buffered trisodium citrate $(0.129 \mathrm{~mol} / \mathrm{l}$, 9 parts of blood to 1 part of citrate solution). For each blood sample a platelet-rich plasma (PRP) and platelet-poor plasma (PPP) were prepared as follows: Whole blood was centrifuged for $10 \mathrm{~min}$ at $150 \mathrm{xg}$ at $18^{\circ} \mathrm{C}$, and the supernatant platelet-rich plasma (PRP) was removed. The remaining blood was further centrifugated for $15 \mathrm{~min}$ at $2000 \times \mathrm{g}$ at $18^{\circ} \mathrm{C}$.

Anti-Xa and anti-IIa activity assessment: A volume of $1 \mathrm{ml}$ of PPP was mixed with $5 \mu \mathrm{g}$ of each studied product to obtain a final concentration of about $0.5 \mathrm{IU}$ anti-Xa/ml. Subsequently, anti-Xa and anti-IIa activities were measured on STAR analyser using a validated commercial reagent (Diagnostica Stago, Asnieres Sur-seine France) and the anti-Xa /anti-IIa ratio was calculated. Anti-Xa activity was measured using the STA ${ }^{\circledR}$ Rotachrom ${ }^{\circledR}$ Heparin reagent (Diagnostica stago, Asnières sur seine, France). Anti-IIa activity was measured using S-2238 as a substrate.

Thrombin generation inhibition assessment: To study the effect of branded and generic enoxaparin on thrombin generation, PPP from 15 healthy volunteers was spiked with increasing concentrations $(2,4,6$, 8,10 and $20 \mu \mathrm{g} / \mathrm{ml}$ ) of Lovenox ${ }^{\circledR}$ or Enoxa ${ }^{\circledR}$. Thrombin generation was studied in-vitro according to Hemker et al. [10] using the Calibrated Automated Thrombogram (CAT) assay (Thombinoscope b.v.,
Maastricht, The Neterlands). In each of a micro-plate, $80 \mu$ of each PPP were mixed with $20 \mu \mathrm{l}$ of PPP reagent ${ }^{\circledR}$ and $1 / 200$ diluted Innovin ${ }^{\circledR}$ (from Siemens). Control samples of $80 \mu \mathrm{l}$ of PPP spiked with $20 \mu \mathrm{l}$ of thrombin calibrator (Biodis, Stago Laboratory, Asnières, France) were run in parallel with PPP. Thrombin generation was initiated by adding $20 \mu \mathrm{l}$ of triggering solution containing $\mathrm{CaCl}_{2}$ ( $16.7 \mathrm{mM}$ final concentration) and fluorogenic substrate (Z-Gly-Gly-Arg-AMC, Bachem, Bubendorf, Switzerland, $417 \mu \mathrm{M}$ final concentration). A plate reader fluorometer (Fluoroskan Ascent; Thermo Labsystems, Helsinki, Finland) and the appropriate software (Synapse, Maastricht, the Netherlands) were used for the assessment of thrombin generation. Thrombin generation was expressed by the mean rate index (MRI) and endogenous thrombin potential (ETP). MRI is defined as Peak/time to Peak - lag time. The effect of each enoxaparin on thrombin generation was expressed by the half maximal inhibitory concentration of the drug (IC50) that is required to inhibit 50\% in-vitro thrombin generation (IC50 MRI and IC50 ETP). Both IC50 MRI and IC50 ETP were calculated in PPP.

\section{Statistics}

Data are presented as mean \pm SD or median (25\% interquartile range) as appropriate. Previous studies with enoxaparin sodium effects on anti Xa activity in healthy volunteers have shown an intraindividual variance of less than $10 \%$. Thus, assuming a type I error of $\alpha=.05$, a statistical power of $1-\beta=.80$, an equivalence acceptance intervals of $80 \%$ to $125 \%$, and a mean ratio of test versus reference between 0.95 and 1.05, a sample size of $n=80$ in each arm has been calculated to be appropriate for the clinical study. To compare baseline demographic and clinical characteristics between groups, Student $t$ test was used for continuous variables and $\mathrm{Chi} 2$ test for comparison of categorical variables. The unpaired student's $t$ test was used to compare anti-Xa activity values between Lovenox ${ }^{\circledR}$ and Enoxa ${ }^{\circledR}$. Anti Xa/anti IIa ratios, IC50 MRI, and IC50 ETP values in PPP of the generic and the branded enoxaparin were compared by paired Student's t test. P values $<.05$ were considered statistically significant. Statistical analysis was performed with SPSS software version 17.0 (Chicago, IL, USA).

\section{Results}

\section{The clinical study}

A total of 169 patients with ACS were enrolled and completed the study, 86 received Enoxa ${ }^{\circledR}$ and 83 received Lovenox ${ }^{\circledR}$. Demographic characteristics and standard laboratory tests values are shown in Table 1; there were no significant statistical differences between Enoxa and Lovenox ${ }^{\circledR}$ groups with regard to these variables. The mean enoxaparin dose was $7000 \pm 100 \mathrm{IU}$ in Enoxa ${ }^{\circledR}$ group as compared to $6900 \pm 150$ IU in Lovenox ${ }^{\circledR}$ group $(\mathrm{p}=0.54)$. Median anti Xa activity measured 4 hours after the initial bolus was 0.39 IU anti-Xa/ml [95\% CI 0.310.53] and $0.34 \mathrm{IU}$ anti-Xa/ml [95\% CI 0.27-0.53], for the Enoxa ${ }^{\circledR}$ group and Lovenox ${ }^{\circledR}$ group respectively; the difference was not statistically significant $(\mathrm{p}=0.82)$. All the patients were transferred to the cardiology department within 24 hours after their ED admission. No significant difference was observed between both groups with regard to major adverse cardiovascular events at 30 days post-ED admission (Table 2). There were no significant hemorrhagic complications in both groups during the follow-up.

\section{The healthy volunteers study}

The anti-Xa and anti-IIa activities per milligrams of the generic and the branded enoxaparin were similar as was the anti-Xa/anti-IIa ratio (Table2). When thrombin generation was assessed on PPP, both branded and generic enoxaparin showed comparable IC50 MRI (2.5 


\begin{tabular}{|l|c|c|c|}
\hline & $\begin{array}{c}\text { Enoxa }^{\circledR} \\
(\mathrm{n}=86)\end{array}$ & $\begin{array}{c}\text { Lovenox }^{\circledR} \\
(\mathrm{n}=83)\end{array}$ & $\mathbf{p}$ \\
\hline Age (year) mean (SD) & $61.5(12.5)$ & $63.7(10.8)$ & 0.249 \\
\hline Sex ratio (M/F) & 2.0 & 1.6 & 0.465 \\
\hline $\begin{array}{l}\text { Body mass index }\left(\mathrm{kg} \cdot \mathrm{m}^{-2}\right) \text { mean } \\
(\mathrm{SD})\end{array}$ & $27.7(4.2)$ & $26.5(3.5)$ & 0.221 \\
\hline $\begin{array}{l}\text { History of cardiovascular disease } \\
\mathrm{n}(\%)\end{array}$ & $37(43)$ & $44(53)$ & 0.18 \\
\hline Diabetes mellitus $\mathrm{n}(\%)$ & $39(45)$ & $33(40)$ & 0.41 \\
\hline Heart failure $\mathrm{n}(\%)$ & $10(12)$ & $8(10)$ & 0.71 \\
\hline Hemoglobin $(\mathrm{g} / \mathrm{dl})$ & $12.4 \pm 1.8$ & $12.6 \pm 2.1$ & 0.52 \\
\hline Platelet count $\left(1000 / \mathrm{mm}^{3}\right)$ & $230 \pm 56$ & $212 \pm 50$ & 0.29 \\
\hline Creatinine ( $\mu$ mol/l) & $108.8 \pm 43.0$ & $106.5 \pm 70.3$ & 0.81 \\
\hline $\begin{array}{l}\text { Glomerular filtration rate } \\
\text { PT (\%) }\end{array}$ & $86.4 \pm 21.2$ & $86.9 \pm 18.2$ & 0.94 \\
\hline aPTT (sec) & $30.3 \pm 7.8$ & $30.2 \pm 9.4$ & 0.77 \\
\hline
\end{tabular}

Table 1: Demographic characteristics and biological assessment at baseline in patients with acute coronary syndrome.

\begin{tabular}{|c|c|c|c|}
\hline & $\begin{array}{c}\operatorname{Enoxa}^{\circledR} \\
(n=86)\end{array}$ & $\begin{array}{l}\text { Lovenox }^{\circledR} \\
(n=83)\end{array}$ & $\mathbf{p}$ \\
\hline \multicolumn{4}{|l|}{ Clinical Study } \\
\hline \multicolumn{4}{|c|}{$\begin{array}{l}30 \text { days major cardio-vascular events } \\
\mathrm{n}(\%)\end{array}$} \\
\hline death & $3(3.4)$ & $3(3.5)$ & NS \\
\hline acute reperfusion & $1(1.1)$ & 0 & \\
\hline stroke & 0 & $1(1.2)$ & \\
\hline combined events & $4(4.5)$ & $4(4.7)$ & \\
\hline $\begin{array}{l}\text { Anti-Xa activity median }(95 \% \mathrm{Cl}) \\
\text { Baseline (anti-Xa IU/ml) }\end{array}$ & 0 & 0 & - \\
\hline After 4hours (anti-Xa IU/ml) & $\begin{array}{l}0.39(0.31- \\
0.53)\end{array}$ & $\begin{array}{l}0.34(0.27- \\
0.53)\end{array}$ & NS \\
\hline \multicolumn{4}{|l|}{ Healthy volunteers study } \\
\hline 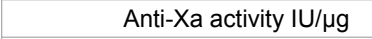 & 0.12 & 0.11 & NS \\
\hline Anti-Ila activity IU/Mg & 0.03 & 0.03 & \\
\hline Anti-Xa/Anti-Ila ratio & 3.8 & 3.6 & \\
\hline
\end{tabular}

\section{NS : not significant}

Table 2: Clinical outcome, plasma anti-Xa and anti-Ila activity with Lovenox® and Enoxa ${ }^{\circledR}$

$\mu \mathrm{g} / \mathrm{ml} \pm 0.2 \mu \mathrm{g} / \mathrm{ml})$ versus $(2.3 \mu \mathrm{g} / \mathrm{ml} \pm 0.1 \mu \mathrm{g} / \mathrm{ml})$ respectively for Lovenox $^{\circledR}$ and $\operatorname{Enoxa}^{\circledR}(\mathrm{p}=0.2)$ and $(4.8 \mu \mathrm{g} / \mathrm{ml} \pm 0.8 \mu \mathrm{g} / \mathrm{ml})$ versus $(4.1$ $\mu \mathrm{g} / \mathrm{ml} \pm 0.1 \mu \mathrm{g} / \mathrm{ml})$ for IC50 ETP in Lovenox ${ }^{\circledR}$ and Enoxa ${ }^{\circledR}$ respectively $(\mathrm{p}=0.2)$ (Figure 1).

\section{Discussion}

Recently, several generic LMWHs have become available worldwide [11]. This study was carried out to compare the anticoagulant potency and pharmacodynamic responses of branded enoxaparin (Lovenox ${ }^{\circledR}$ ) with a generic enoxaparin $\left(\right.$ Enoxa $\left.^{\circledR}\right)$. It is the first Tunisian report of a bioequivalence between original and generic versions of enoxaparin using validated parameters in a clinical trial conducted on ACS patients and experimental study performed in healthy volunteers.

Our study showed that bolus administration of equal doses of branded and generic enoxaparin in patients with ACS results to similar levels of plasma anti-Xa activity measured 4 hours after bolus administration. In addition, the in-vitro anti-Xa and anti-IIa activities as well as the anti-Xa/anti-IIa ratio were not significantly different between Lovenox ${ }^{\circledR}$ and Enoxa ${ }^{\circledR}$. The effect of generic and branded enoxaparins on thrombin generation in PPP was similar as demonstrated by similar IC50 for both MRI and ETP.
In contrast to many other drugs, heparins cannot be reliably detected in-vivo as a chemical entity; therefore, pharmacodynamic surrogates are usually employed to describe their pharmacokinetic properties and their bioavailability [12]. According to the FDA bioequivalence requirements, pharmacodynamic surrogates of efficacy including anti-Xa activity, anti-IIa activity, and their ratios are established and validated bioequivalence criteria [13,14]. The strength of our study is that in addition to standard tests, we used the thrombin generation tests to assess bioequivalence between the enoxaparin innovator product and its generic version. The information obtained by these tests is particularly important and represents a significant improvement in the assessment of the different Xa inhibitors available [10]. In our study, we showed that the IC50 of Lovenox ${ }^{\circledR}$ and Enoxa ${ }^{\circledR}$ for MRI and ETP were similar in PPP. Taken together, our results are in accordance with those reported in the literature from previous studies where most of generic versions exhibited similarities with branded enoxaparin [8]. However, the present bioequivalence study had several limitations. First, the single-dose design in the clinical study including patients with ACS did not allow us to measure the area under the plasma concentration-time curve of anti-Xa activity which could be more informative than a single test $[15,16]$. However, our results in healthy volunteers indicated that similar anti-Xa/anti-IIa ratio was achieved by the original and the generic enoxaparin. Second, although this study did not specifically address a comparison between the two LMWHs on the basis of clinical outcome criteria, this condition for bioequivalence acceptance was not always required. On the other hand, we believe that compounds which have similar biological effects on the basis of an established criteria of sameness will likely have similar clinical effect. In one recent Tunisian study conducted in post-operative orthopedic patients, it was demonstrated that Enoxa ${ }^{\circ}$ was as effective as Lovenox ${ }^{\mathbb{R}}$ in preventing deep venous thrombosis during 45 days follow-up [17]. Third, the assessment of adverse events was not sufficiently addressed in this study. Occurrence of heparin-induced thrombocytopenia (HIT) is an important safety criteria required for generic LMWH [18]. However, because HIT is reported at a rate of less than $1 \%$ of patients treated with LMWHs, it is not expected to be seen in a single-dose trial as in the present study. Nonetheless, available data did not indicate that the risk of HIT is superior with biosimilar versions of enoxaparin compared to original products [18].

\section{Conclusion}

In conclusion, the generic enoxaparin Enoxa ${ }^{\oplus}$ shares many similarities with originator product Lovenox ${ }^{\mathbb{B}}$ as demonstrated in our study on the basis of the commonly biologic and pharmacodynamic

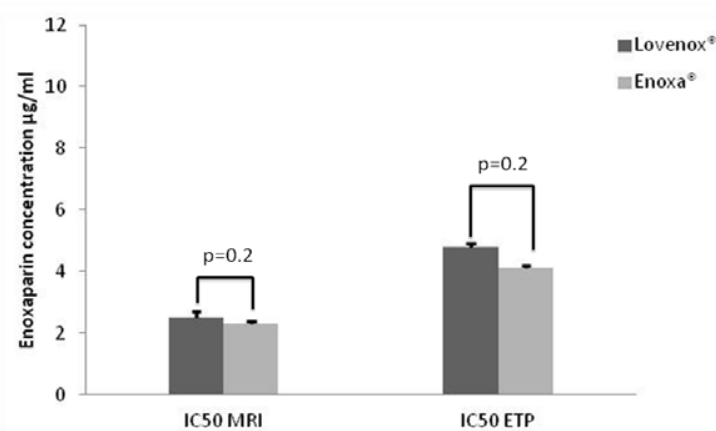

Figure 1: The Lovenox ${ }^{\circledR}$ and Enoxa ${ }^{\circledR}$ concentrations which reduced $50 \%$ of Mean Rate Index (IC50 MRI) and Endogenous Thrombin Potential (IC50 ETP) in platelet-poor plasma. Values are mean \pm SD of 15 experiments. 
Citation: Boubaker H MD, Grissa MH MD, Sassi M MD, Chakroun T MD, Beltaief K MD, et al. (2015) Generic and Branded Enoxaparin Bioequivalence: A Clinical and Experimental Study. J Bioequiv Availab 7: 225-228. doi:10.4172/jbb.1000244

criteria. Accordingly Enoxa ${ }^{\circ}$, as many enoxaparin generics would be an interesting alternative to patients especially those living in low income countries.

\section{Acknowledgments}

SN conceived the study, and designed the trial. SN, WB, RB, MHG, I E and $\mathrm{HB}$ supervised the conduct of the trial and data collection; GTG, MH, TC, and KB undertook recruitment of patients and managed the data, including quality control; $\mathrm{SN}$ and RR performed statistical analysis and analyzed the data; SN drafted the manuscript; TC and GTG revised the manuscript and all authors contributed substantially to its revision; SN took responsibility for the paper as a whole.

We thank Mrs Raoudha Tabka, PharmD for her technical assistance.

\section{Conflict of Interest}

This work was supported by Medis Laboratory, Tunisia.

None of the authors received a personal grant to participate in the study.

\section{Running Head}

New generic enoxaparin

\section{Source of Support}

Grant from the Tunisian State Department of Research and Research department of Medis Laboratory, Tunisia.

\section{References}

1. Samama MM (2002) Synthetic direct and indirect factor Xa inhibitors. Thromb Res 106: V267-273.

2. Lee S, Gibson CM (2007) Enoxaparin in acute coronary syndromes. Expert Rev Cardiovasc Ther 5: 387-399.

3. Carter NJ, McCormack PL, Plosker GL (2008) Enoxaparin: a review of its use in ST-segment elevation myocardial infarction. Drugs 68: 691-710.

4. Harrington RA, Becker RC, Cannon CP, Gutterman D, Lincoff AM, et al. (2008) Antithrombotic therapy for non-ST-segment elevation acute coronary syndromes: American College of Chest Physicians Evidence-Based Clinical Practice Guidelines (8th Edition). Chest 133: 670S-707S.

5. Kearon C, Kahn SR, Agnelli G, Goldhaber S, Raskob GE, et al. (2008) Antithrombotic therapy for venous thromboembolic disease: American College of Chest Physicians Evidence-Based Clinical Practice Guidelines (8th Edition). Chest 133: 454S-545S.
6. Feng L, Shen-Tu J, Liu J, Chen J, Wu L, et al. (2009) Bioequivalence of generic and branded subcutaneous enoxaparin: a single-dose, randomized-sequence open-label, two-period crossover study in healthy Chinese male subjects. Clin Ther 31: 1559-1567.

7. Sharma V, Madhu S, Natarajan P, Muniyandi G, Jaiswal V, et al. (2010) A comparison of the biological activity of 2 formulations of enoxaparin in 12 healthy volunteers. Clin Appl Thromb Hemost 16: 387-393.

8. Glauser BF, Vairo BC, Oliveira SN, Cinelli LP, Pereira MS, et al. (2012) Structure and haemostatic effects of generic versions of enoxaparin available for clinical use in Brazil: similarity to the original drug. Thromb Haemost 107 302-314.

9. Drouet $L$ (2012) Low molecular weight heparin biosimilars: how much similarity for how much clinical benefit? Target Oncol 7 Suppl 1: S35-42.

10. Hemker HC, Al Dieri R, De Smedt E, Béguin S (2006) Thrombin generation, a function test of the haemostatic-thrombotic system. Thromb Haemost 96: 553561.

11. Ofosu FA1 (2011) The United States Food and Drugs Administration approves a generic enoxaparin. Clin Appl Thromb Hemost 17: 5-8.

12. Harenberg $\mathrm{J}$ (2011) Overview on guidelines and recommendations for generic low-molecular-weight heparins. Thromb Res 127: S100-104.

13. FDA News Release (2010) fda.gov/NewsEvents/Newsroom/ PressAnnouncements/ucm220092.hm.

14. Nicolau JC, Cohen M, Montalescot G (2009) Differences among low-molecularweight heparins: evidence in patients with acute coronary syndromes. J Cardiovasc Pharmacol 53: 440-445.

15. Kuczka K, Harder S, Picard-Willems B, Warnke A, Donath F, et al. (2008) Biomarkers and coagulation tests for assessing the biosimilarity of a generic low-Molecular-weight heparin: results of a study in healthy subjects with enoxaparin. J Clin Pharmacol 48: 1189-1196.

16. Hirsh J, Anand SS, Halperin JL, Fuster V (2001) Mechanism of action and pharmacology of unfractionated heparin. Arterioscler Thromb Vasc Biol 21 1094-1096.

17. Zarrouk A, Bouzidi R, Azaiez M, Houissa M, Kooli W (2012) Vein thrombosis in patients undergoing arthroplasty. Meeting abstract in the 33rd SICOT \& 17th PAOA Orthopaedic World Conference Dubai, United Arab Emirates.

18. Jeske W, Walenga JM, Hoppensteadt D, Fareed J (2013) Update on the safety and bioequivalence of biosimilars - focus on enoxaparin. Drug Healthc Patient Saf 5: 133-141. 